\title{
Models and Menstruation: Spare Rib Magazine, Feminism, Femininity and Pleasure
}

\section{by Selina Todd}

First published in Studies in Social and Political Thought 1, 1999.

The traditional women's magazine appears anathema to feminism, its blend of romance, beauty and domesticity portraying and maintaining female objectification within the feminine ideal. In June 1972 this genre was challenged from within, with the appearance of a new women's magazine on the shelves of Britain's newsagents - at least, on the shelves of those who agreed to stock it. WH Smith was among those who refused to carry Spare Rib, a magazine that aimed to explore the ideas of the emerging Women's Liberation Movement. Spare Rib was published until 1993, but my article concentrates on its first 21 issues - from June 1972 to March 1974 - which mark the period before 'a more articulate feminist editorial content emerged.' Marsha Rowe, one of the magazine's founders, contends that the early Spare Rib was 'a jumble ... carrying contradictory messages. ${ }^{1}$ It is for this reason that an examination of the magazine's early years is valuable. My study will explore the dilemmas and contradictions hinted at by Rowe, which, I shall argue, provide an important insight into the evolution of a wider feminist challenge to the social and cultural construction of femininity, and the difficulties inherent in such a process.

This article is divided into five sections. It is not simply a textual analysis, but seeks to explore the influence of, and Spare Rib's impact on, the social and political context from which it emerged. Before turning to the feminist debates within the magazine, then, it is important to note to whom it was addressed and from where it emerged: the focus of the first section. I will then discuss the difficulties inherent in Spare Rib's, and second wave feminism's, attempts to theorise women's oppression, particularly when dealing with women's pleasure and the construction of femininity. Thirdly, I will explore why despite the fact that personal life is the conventional realm of women's magazines, it was difficult for Spare Rib to embrace the feminist philosophy that 'the personal is political.' Section four will examine the magazine's attempts to explore the relationship between femininity and 
feminism, and the questions this raises about the social construction of pleasure and womanhood. In conclusion, the legacy of the early Spare Rib for feminists crafting a critique of femininity, while sympathetically exploring and possibly celebrating women's pleasure, will be discussed.

In his study of women's magazines, Brian Braithwaite has claimed that Spare $R i b$ was aimed at a fringe market of politically conscious feminists. ${ }^{2}$ Braithwaite's judgement is the result of scant research and an unquestioning acceptance of the popular view that feminism has always been a fringe movement. In fact, the magazine's editorial approach and general content in the early issues suggest that its founders in fact hoped to appeal to feminists and non-feminists alike. The traditional ingredients of women's magazines were integral to Spare Rib: the home, beauty, fashion and personal relationships. Its readership did appear to be fairly diverse: letters pages suggest that although most readers were young, middle class women, a combination of middle-aged housewives and working women, single and married women of all ages and those suspicious of women's liberation as well as those active in the movement not only read, but actively contributed to the early Spare Rib. ${ }^{3}$ The magazine's first issue sold out, and thereafter a fairly small but steady average monthly distribution of approximately 20,000 copies was established. ${ }^{4}$

From its first issue, Spare Rib sought to distance itself from traditional women's magazines. Editorials proclaimed its purpose as exploring alternatives to women's conventional, gendered role. ${ }^{5}$ This posed a challenge to a well-established form of women's pleasure - the commercial magazine - and the conventional social and cultural norms which that genre reflected. Spare Rib thus identified itself with the concerns of second wave feminism, which since its emergence in the USA during the mid-1960s, had been as much concerned with cultural and social change as with political, legal and economic emancipation. One of the first protests carried out by second wave feminists in Britain, the disruption of the 1970 Miss World beauty pageant, dramatically demonstrated active opposition to the objectification of women by the mass media and consumer culture. This protest embodied sentiments similar to those expressed in popular contemporary feminist texts such as Millett's Sexual Politics (1971) and Greer's The Female Eunuch (1970). The Women's Liberation Movement, as this wave of feminism defined itself, thus had great implications for the most personal aspects of women's lives. Their relationships with men, the gendered nature of domestic responsibility and popular perceptions of femininity were scrutinised and became matters for 
rigorous debate.

Students of the women's movement encounter similar difficulties to those faced by any researcher of social and cultural developments; tracing and connecting intellectual and social changes is a highly problematic process. 'The Women's Liberation Movement' is a deceptively coherent term, covering a diverse range of localised activity and a proliferation of political and social attitudes. As Barbara Caine points out, while a vast amount of primary material documenting the women's movement remains, it paints a highly selective picture of feminism in the early and mid 1970s. ${ }^{6}$ The first national Women's Liberation Conference held at Ruskin College, Oxford in 1970 has proved an important reference point for subsequent historical research, partly because this was one of the first (and few) events at which a large number of feminists debated and recorded their aims and ideas, and partly because a number of those present were already well-known in political or academic circles (for example, Juliet Mitchell), while others were to rise to prominence in the following decade. The work of participants such as Sheila Rowbotham and Sally Alexander has greatly influenced the construction of the history of second wave feminism. Their research, and biographical accounts such as Truth, Dare or Promise and Once a Feminist have produced a detailed and valuable narrative of the women's movement, but one which at times neglects women outside the Ruskin scene, and the 'anguish, bitterness, embarrassment, exhilaration, determination and hope' experienced by them. ${ }^{7}$

Why did Women's Liberation, the prompt behind Spare Rib's inception, gain popularity in Britain? Mitchell identified the influence that student activism, the USA's Civil Rights movement and the hippy culture of the mid to late 1960s had on young women's attitudes to sexual equality. ${ }^{8}$ The New Left, characterised in Britain by intellectuals like EP Thompson and Raymond Williams, developed and connected cultural critiques of capitalism to more traditional Marxist economic analyses, and these informed student activism. The hippies' rejection of middle class respectability did not directly challenge the existing socio-economic structure, but it did pose a collective alternative to the nuclear family and consumer culture. American Civil Rights protestors embodied the appeal of identity politics, demanding political and legal change through civil disobedience while challenging cultural norms by promoting an alternative popular culture. Identity politics, together with challenges to consumerism, family life and sexual morality clearly had the potential to undermine traditional gender roles.

As Coote and Campbell note, many women were prompted to challenge sex stereotyping by their 'knowledge of radical politics combined 
with a sense of exclusion from it. ${ }^{\prime 9}$ The faith that imminent socialist revolution would end inequality was, for many women activists, tempered by suspicion that their own part in post-revolutionary society could be confined to making the tea. Sheila Rowbotham was among those whose growing belief that politics should be concerned with personal relations as well as institutional reform prompted her 'own realisation of the depth and extent of my colonisation [which] came with the force of an electric shock.' ${ }^{10}$ In addition to such unease, dissatisfaction with domesticity was expressed with increasing openness by young wives and mothers in the late 1960s and early 1970s. The expansion of higher education in the 1960s appeared to offer young middle class women an alternative to their mothers' domestic fate. Many of those who became active in the Women's Liberation Movement spoke of a feeling of disappointment that this apparent promise was unfulfilled; on entering marriage and motherhood many found it a stark contrast to the freedom of student life and realised that more social change was required if their situation was to alter. ${ }^{11}$

Frustration was compounded by the continued existence of sexual discrimination in political, legal and economic spheres. Full-time women workers' hourly earnings still averaged only 59 per cent of men's in the mid1960s. ${ }^{12}$ Working class women's indignation at such inequality exploded in equal pay disputes during the late 1960s, the best known being the 1968 action by women working at Ford's Dagenham plant. The general socioeconomic context undoubtedly facilitated such expressions of discontent; practically full employment strengthened workers' power, and women were aware that their place in the employment market was fairly secure.

Organisation among working class and middle class women thus grew during the later 1960s and early 1970s. While no absolute division can be made, working class women tended to organise more around labour issues, while middle class women became involved in consciousness raising activities designed to explore women's personal experiences and collective concerns. The National Joint Action Campaign for Women's Equal Rights was formed in 1968, prompted by the discontent of women workers, and the early 1970s witnessed a continuation of equal pay disputes and attempts to build women's caucuses within the labour movement. By late 1969 three predominantly middle class women's groups had emerged in Essex and London. The growth of such groups was ad hoc and localised, and the first national gathering was the 1970 Women's Liberation Conference, organised largely by academics and students involved in the left wing history workshop movement.

How did Spare Rib's founders fit into this picture? Many of them, such as Marsha Rowe and Rosie Boycott, had previously worked in the 
underground press which in the later 1960s had grown enormously. It promoted the music, sexual permissiveness and libertarianism of youth counter-culture, stressing personal expression as an alternative to established moral and social conventions. This promise of liberation from sexual taboo and moral regulation rarely translated into reality for women, who still had to protect themselves against unwanted pregnancies, were subject to sexobjectification in the alternative as much as in the mainstream media and, as employees of the underground press, experienced exploitation in a similar manner to women participating in left wing politics. ${ }^{13} \mathrm{~A}$ meeting of women involved in the underground press, organised by Rowe in December 1971 - the first of a series from which Spare Rib emerged - aroused emotions in a similar manner to the first women's groups, with 'women voicing the other side of sexual permissiveness ... the room seemed to swirl with emotion so long suppressed.'14

\section{II}

Unsurprisingly, given the founders' backgrounds, early issues of Spare Rib sought to interrogate the social construction of female identity. Many contributions attempted to connect anti-sexism with the established socialist critique of capitalism. Boycott's article 'The price of beauty' explored the role of the cosmetics industry in maintaining the capitalist free market and also women's objectification. ${ }^{15}$ Anti-consumerism was expressed by the magazine's layout, which spurned the glossy appearance of the commercial women's magazines, using instead the bold but basic style of the 1960s alternative press. The cultural critique of capitalism was developed by explorations of alternative lifestyles. An article entitled 'Day nursery revolution' focused on a collectively run childcare centre, suggesting that such initiatives could encourage a more equal division of childcare responsibility between men and women and could more generally promote an egalitarian, democratic educational ethos. ${ }^{16}$ Such features highlight the influence of a wider feminist belief that women's demands - in this case for more childcare - must be answered by anti-capitalist as well as antisexist means. The title of the article is typical of Spare Rib's optimism that a cultural revolution against capitalism and patriarchy was under way. The management of the magazine itself aimed at a woman-friendly, antihierarchical structure; within a year, an editorial collective had taken control, and readers were constantly encouraged to contribute to Spare Rib's content.

Women's oppression cannot simply be fitted neatly into a Marxist paradigm, however. A failure fully to address the complexities of theorising women's oppression dogged the early Spare Rib. When Carol Dix, reviewing 
Rowbotham's Hidden from History in Spare Rib, commented 'at times Sheila confuses "men" with "capitalism" - which is worse?' she voiced a question that Spare Rib consistently evaded. There was a marked reluctance to explore the connections and contradictions between claims that gender oppression was initiated by the political and economic structures of capitalism, or by patriarchal power, wielded by male 'comrades.' The class analysis of society formulated by socialism could not be utilised to explore women's identity as a distinct social group, nor the facets of that identity, whether their shared biological characteristics, or the feminine fantasy of beauty, appearance and romance which, whether individual women gain pleasure from it or not, exerts a powerful influence on womanhood.

\section{III}

I will now turn to Spare Rib's treatment of the traditional realm of women's magazines: women's personal lives, and investigate how the magazine tackled the second wave feminist tenet, 'the personal is political.' I shall argue that the magazine's approach to this highlights a dilemma in feminist thought when dealing with the division between public and personal life which, while partially resolved in the intervening decades, is still a problem for feminism today. Spare Rib's early attempts to construct a feminist analysis of sexual oppression are potential indicators of a way forward for contemporary feminists who wish to tackle gender inequality in sexual and familial relations without either essentialising women's identity within a feminine discourse, or adopting wholesale a dubious post-structuralist agenda, articulated by thinkers such as Denise Riley, who argues that 'no one needs to believe in the "solidity" of women,' as 'women is ... an unstable category ... which need not worry us.' ${ }^{17}$

One of the most exciting aspects of the early Spare Rib was its attempt to explore women's pleasure without ascribing to them an innate femininity. It thus differed markedly from the proliferation of magazines for young women which appeared in the late 1960s and early 1970s, such as Nova and Cosmopolitan. These magazines were influenced by the Women's Liberation Movement and sought to appeal to a generation of 'liberated' women. They tackled issues not previously covered by the genre, such as careers, and were more open about sexual health and relations. Despite this shift, their outlook was essentially conventional; like older magazines, they did not challenge the existence of distinct, gendered roles, simply suggesting that individual effort and a feminine touch provided the key to women's success in the maledominated world of work, as well as in the domestic sphere.

Spare Rib questioned this individualism by suggesting that women 
should collectively challenge female objectification. The magazine ran an increasing number of self-help guides on health and reproductive rights, with features on peer group therapy and self-examination groups. ${ }^{18}$ This demonstrated a growing feminist awareness of the subjectivity of science and medicine, and a wish to expose the myth that there existed an 'ideal' woman who should be aspired to. Readers were encouraged to share their own experiences for the benefit of others. Many wrote in to ask for or to offer advice on divorce and contraception. Anna Raeburn, a member of the editorial collective, clearly expressed the magazine's desired approach when she commented, 'we do have a lot of common experience. Let's work out of that. ${ }^{\prime 19}$ In a similar manner to the emerging women's groups, Spare Rib's workers, contributors and readers 'collectively ... began to reconstruct the boundaries of normal womanhood. ${ }^{20}$

One of the most celebrated achievements of second wave feminism is embodied in its philosophy that 'the personal is political.' The critical scrutiny of sexual and familial relations undertaken by many feminist researchers has proved invaluable in establishing that the domestic sphere, and women's lives within it, must be given serious consideration within academic research and political thought. In recent years, doubts that any unified 'self,' let alone group, can exist have led to a move towards allowing individual women to articulate their own stories and an increasing scepticism among some feminist researchers over earlier attempts to construct a narrative of women's history; Rowbotham's attempt to rescue those women 'hidden from history' is viewed as patronising and perhaps essentialising. This has led to valuable work, with life history and autobiography being taken increasingly seriously within academic research. Yet it is important that feminist research does not discard analysis and generalisation. The content of Spare Rib's 'Sex page' demonstrates that without this, individual women's stories, while interesting, pose no challenge to patriarchy. The page initially aimed to answer women's queries about their bodies and sexuality, and thus raise awareness of shared concerns. In practice, the format was that of the conventional problem page, with Raeburn, the resident agony aunt, offering individual advice to concerned readers. While her answers were open and informative, there was no attempt to analyse the social construction of sexual relations, and no opportunity for women to define their desires collectively. The onus remained on individual women to change themselves or their partner rather than to devise collective analysis and action. ${ }^{21}$ 'Personal' experience was aired and shared - but the issues it raised were ignored.

This approach to 'personal' life yet again highlights the need for ongoing feminist research to attempt to construct analytical tools with which 
to examine women's oppression. A disjuncture clearly exists between the feminist approach to 'public' politics and 'personal' life. One of the most important achievements of feminists in the 1970s was in highlighting the need to address violence against women, resulting in the opening of statesupported women's refuges, and pressure for women to be treated more sympathetically by the police and courts. Spare Rib played an important role in this, publicising the first women's refuge and examining the experience of women who came into contact with the legal system, in articles such as 'Battered women: how to use the law,' and an article on 'Rape' which attempted to analyse sexual assault as a consequence of capitalism and patriarchy.22 Yet the analysis of women's treatment by the courts and state is not extended to their relationships with men; the article on rape concludes that violence against women is 'difficult to understand,' and will end only with the evolution of a new relationship between the sexes 'which is not built out of dominance and submission. ${ }^{23}$

Such work was a worthy exploration of previously uncharted territory for the popular and underground press, but it is weakened by this underlying ambiguity. While critiques of capitalism provided many feminists with a framework in which to explore institutionalised sexism, formulating tools with which to analyse personal relationships was a harder task. It was hard to challenge the prevailing belief, upheld in most women's magazines, that relationships were outside the realm of political and social analysis; easier to maintain an uneasy silence.

Uncertainty about just how far the personal was political reflected a dilemma inherent in the politicisation of personal life. Lewis claims that the 1960s and 1970s witnessed the deregulation of personal life. She points to legislation such as the 1967 Abortion Act and the 1969 Divorce Act, as well as the increasing availability of contraception and the discourse of sexual permissiveness which all appeared to extend women's control over their bodies and choice over their lifestyle. ${ }^{24}$ The legacy of sexual permissiveness influenced many feminists; liberation according to Greer should enable women to enjoy 'real' sex - heterosex, with as much promiscuity as they chose. ${ }^{25}$ Many early Spare Rib features also assumed the existence of an ideal (hetero) sexuality beneath the layers of capitalist and patriarchal social conditioning; Raeburn felt that women's sexual anxieties were the 'product of a society which programmes us into sexual deformity. ${ }^{26}$ The agenda of sexual permissiveness did not necessarily question the biological construction of sexuality, and thus many feminists unthinkingly accepted this as given. It fuelled a dilemma that Spare Rib embodied: how could an essentially liberal attitude to personal life which emphasised individual choice be transformed into a political analysis of a social group's collective 
experience?

The answer is that it cannot be so transformed, as movements and doctrines other than feminism have demonstrated. The early form of libertarian feminism which informed many of the attitudes present in Spare Rib gave way to two developments: the growth of liberal feminism which has continued to evacuate the area of sexuality, claiming that free choice must rule, and the development of a more 'radical' but at times dogmatic body of theory which strongly influenced the later Spare Rib and whose early appearances will be touched upon in the next section. Liberal feminism has found itself in a dilemma faced by many other political theories which attempt a laissez faire approach, wherever they are located on the political spectrum. The New Right's belief in the minimalist state did not prevent its Thatcherite advocates utilising the welfare state to penalise what they viewed as immorality; frequently with dire consequences for many groups of women. This combination of laissez faire and interventionism has likewise characterised the popular brand of liberal feminism articulated in women's magazines like Cosmopolitan, which demands a level playing field for men and women in the public sphere but largely ignores inequality in sexual politics because its denial that women's oppression amounts to more than a few legislative hitches cannot find a satisfactory analysis of this area of women's lives.

The way forward for feminism is to engage women in collective debate about aspects of sexuality which can be seen as being in common, and to continue to scrutinise means by which the state, but also masculinity , contribute to sexual oppression. This involves engaging with and possibly subverting conventional forms of women's pleasure - as Spare Rib did with the women's magazine. In 1973 Spare Rib published a letter from a married woman, with no experience of the women's movement other than that gleaned from the magazine, criticising the 'Sex page' for problematising women by treating sexuality as an individual concern rather than a matter for collective analysis. ${ }^{27}$ This possibly alerted the editorial collective to a more widespread unease, for the problem page format disappeared just two issues later, the reason given being that the collective wanted to develop an approach to sexuality that did not seek to 'hand out answers to problems, like a doctor giving valium to a housewife.' ${ }^{28}$ The analogy is suggestive: feminists were highly critical of the way in which housewives had been problematised in the 1950s and 1960s as suffering individual neuroses and here the writers of Spare Rib posited as an alternative a form of collective analysis based on capitalism and patriarchy. This shift, from articulating women's dissatisfaction to addressing its causes, marked a wider development in feminist theory; that it affected Spare Rib as the result of 
readers' letters demonstrates the importance of the magazine in making feminist debate accessible.

\section{IV}

Spare $R i b^{\prime}$ s approach to the relationship between women's pleasure, femininity and feminism is possibly its most revealing and relevant aspect for contemporary feminism. In common with other women's magazines, Spare Rib's early issues included many articles on lifestyle; unlike its predecessors, the magazine's editorial collective was keen from the first issue to interrogate the myth of the feminine ideal, confronting the fact that the creation of a feminine identity took a great deal of effort and did not reflect women's 'natural' state. Issue one's centre spread was a spoof fashion feature, 'How the real half dress,' based on a street survey of both women's and men's attitudes to clothing. A regular feature, 'Face value' was launched in the same issue, which attempted to deal with body care from a viewpoint that stressed health and comfort rather than traditional notions of beauty. ${ }^{29}$ The contribution of popular imagery to creating and maintaining the feminine ideal was increasingly highlighted through Spare Rib: issue 8 contained an article by Anna Coote exposing sexist car advertisements, and in later issues a regular column appeared which by featuring similar offenders, stressed the need to monitor and censure sexist imagery. ${ }^{30}$

Spare Rib's confrontation of blatant sexism was, as Winship points out, undermined by its own visual content. ${ }^{31}$ Early cover pictures were strikingly similar to those of its commercial rivals, depicting good looking, smiling, and passive women. Such images serve to demonstrate the lack of any unified feminist 'line' within the editorial collective, but were also the result of social and economic circumstance. Lack of opportunities for women in the male-dominated fields of journalism, photography and graphic design meant that few had developed skills in these areas - only two of Spare Rib's editorial collective, Rowe and Boycott, possessed editorial experience. The magazine thus initially employed much male expertise, and the inclination to develop a feminist approach to magazine layout was at first secondary to the desire to produce a professional product.

The contradictions inherent in Spare Rib's visual content also demonstrate how creativity within oppositional ventures can be so easily constrained by commercial considerations. While the magazine did not rely on conventional advertising as heavily as more mainstream publications, it did run some advertisements, and these frequently perpetuated stereotypical gendered imagery. An article exposing sexist advertising in issue 20 ironically appeared alongside an advertisement for kitchen appliances which 
featured a young woman revelling in domestic bliss. ${ }^{32}$ This tension was a result of the embryonic state of feminist enterprise; in later years, feminist and left wing bookshops, performance and travel initiatives were able to offer mutual support. In its early years, the struggle between pragmatism and idealism that marks any oppositional venture was played out through the pages of Spare Rib. While this resulted in contradictory images and at times subverted the magazine's feminist message, such ventures cannot be condemned. It is hard to define how far compromise can go, but perhaps the words of a member of the Co-operative Movement - another movement dedicated to providing social and cultural as well as economic alternatives to the prevailing norm - could provide a guide: 'The whole is better than a part, but it would be unwise not to accomplish in part what we desire and stand so much in need of, because we cannot at once realise it perfectly.' 33

The ambiguity surrounding the relationship between femininity and feminism within Spare Rib also reflected an important ongoing dilemma for feminist theory. Growing awareness of the social and cultural construction of femininity, highlighted by protests like that against the Miss World contest, was accompanied by a desire to celebrate women's collective identity, of which femininity was clearly an integral element. Years later, many women could still remember what they had worn to the Ruskin conference, and the 'mini sweater dress, long black leather boots' and 'lots of eye makeup' indicate the influence of London fashion as opposed to the politics of appearance which later became so important within sections of the women's movement. ${ }^{34}$ As Steedman has noted, clothing and appearance have always been an important and at times enjoyable means of women developing and conveying a sense of identity. ${ }^{35}$ As feminists tentatively began to explore the relationship between feminism and femininity, many probably agreed with Rowbotham's ambivalence when she admitted, 'I am confused about the relevance of fashion, clothes and make-up.' ${ }^{36}$

In exploring women's liberation within the established genre of women's magazines, Spare Rib acknowledged the coexistence of femininity and feminism. Many articles adopted a similar approach to that articulated by Greer, who felt that women could use fashion and cosmetics for enjoyment while rejecting the notion that they defined female identity or personal esteem. ${ }^{37}$ Issue 18 carried an article typical of Spare Rib's exploration of the influences on women's appearance. In a light-hearted, first person account of a feminist's decision to have her hair cropped, author K. Durbin openly expressed mixed feelings; while feminism prompted the haircut she had decided comfort and ease counted more than feminine appearance - 'since I'm human (and heterosexual) as well as feminist, I can't pretend it's not important to me to know I can attract men who attract me.' ${ }^{38}$ This 
indicated a refreshing approach, one which questioned the significance of femininity and its links with women's objectification, but that also accepted the importance of and enjoyment gained from traditionally feminine concerns by many women.

Durbin's words also, however, convey ambivalence about the relationship between feminism and femininity. By defining herself as human and heterosexual as well as a feminist Durbin's concern over beauty and sexuality is portrayed as divorced from a 'proper' feminist sensibility. Feminism and femininity coexist uneasily throughout Spare Rib largely because of the widely held, unspoken assumption of a 'proper' feminist identity. The subtitle of issue one's 'Face value': 'Behind the dirt,' suggested that women's real identity would be uncovered only after the rejection of the taint of cosmetics, and the patriarchal assumptions they stand for. ${ }^{39}$ As the magazine developed, the connections between femininity and pleasure were met with silence and evasion rather than exploration. Reviewing the romantic film 40 Carats, a typical heterosexual love story, Lyn Gambles urged feminists to beware of its 'seductive' pleasure. Her tone suggested that enjoyment of the romantic myth, expressed through so much popular literature, music and film, was incompatible with a feminist consciousness and reflected 'immature notions of love.' ${ }^{40}$ Spare Rib increasingly glossed over the problematic relationship between feminism and femininity, puritan disapproval frequently substituted for potential explorations of pleasure.

Spare $R i b^{\prime}$ s treatment of this issue resulted in its presentation to readers of a superwoman - an ideal feminist. This superwoman rejected all femininity, but the concept was common to conventional women's magazines, which traditionally created an ideal woman for readers to emulate. ${ }^{41}$ The early Spare Rib was refreshing and exciting in giving expression to a wide range of attitudes towards femininity. It is unfortunate that this did not develop into a deeper examination of femininity, pleasure and feminism, which could have sympathetically explored the difficulties in jettisoning femininity wholesale, and the question of whether it is desirable to do so. Instead, this controversy was evacuated rather than confronted as the magazine developed.

\section{V}

Winship notes that the early Spare Rib subjected women's concerns, interests and oppression to a 'new but as yet unfocused eye; this was the excitement and adventure of the early issues. ${ }^{42}$ This explains both the magazine's weaknesses and its strengths. The ambiguities and contradictions present are understandable, for this was an ambitious project; an attempt to 
articulate and explore women's experiences from a feminist standpoint, which preceded the evolution of a substantial body of feminist theory. Yet these ambiguities possessed a value for contemporary readers, and remain significant for later researchers. The glib, glossy portrayal of women's lives found in mainstream women's magazines was rejected. Spare Rib confronted the issues posed by women's oppression and examined the dilemmas facing feminists; this openness encouraged women to feel their own views and experiences were valuable contributions to the evolution of contemporary feminism. It suggested that 'woman' was a term encompassing multiple identities that were fluid and redefinable, but essentially defined a collective group which could unite to create a foundation for new analyses of sexual oppression and posit a challenge to that oppression.

This does not necessitate the denial of the existence of a single 'self,' in the manner of post-structuralism, but is a means of avoiding the debate into which second wave feminism has habitually become embroiled over the character of 'natural' womanhood. The strength of the early Spare Rib lay in its willingness to take risks: to proclaim itself an oppositional venture within a highly conventional genre, to seek to accommodate and celebrate women's pleasure while simultaneously exploring in an informative and enjoyable manner the everyday aspects of women's lives. The significance of Spare Rib was that it suggested that women's pleasure was an area that feminism should engage with; it offered women a space to explore the potentialities of the relationship between the feminine fantasy embodied in the fashion model, and the reality of women's lives: work, family, sex, bodies. It remains an exciting area for development.

Selina Todd is a writer and Professor of Modern History at Oxford University. She writes on class, inequality, working-class history, feminism and women's lives in modern Britain. Her most recent book is The People: The Rise and Fall of the Working Class, 1910-2010 (2015). This paper was first published when the author was about to begin a DPhil at the University of Sussex.

\section{Endnotes}

${ }^{1}$ M. Rowe, Spare Rib Reader, Penguin. 1982, p. 20.

${ }^{2}$ Ibid., p. 192. 
${ }^{3}$ R. Ballaster, Women's Worlds: Ideology, Femininity and the Women's Magazine, Macmillan, 1991, pp.. 17-18.

${ }^{4}$ B. Braithwaite, Women's Magazines: The First 300 Years, Peter Owen, 1995, p. 102.

5 ‘Editorial,' Spare Rib 1, 1972, p. 3.

${ }^{6}$ Caine, English Feminism 1780-1980, OUP, 1997, p. 263.

${ }^{7}$ Rowe, 1982, op cit., p. 13. See also L. Heron (ed.), Truth, Dare or Promise: Girls Growing Up in the Fifties, Virago, 1985; and M. Wandor (ed.), Once a Feminist, Virago, 1990.

${ }^{8}$ J. Mitchell, Woman's Estate, Penguin, 1971, pp. 29-35.

${ }^{9}$ A. Coote and B. Campbell, Sweet Freedom, Blackwell, 1987, p. 7.

${ }^{10}$ S. Rowbotham. Woman's Consciousness, Man's World, Penguin, 1973, p. 39.

${ }^{11}$ A. Oakley, Taking it like a Woman, Cape, 1984, pp. 58-80.

${ }^{12} \mathrm{~J}$. Lewis, Women in Postwar Britain, Blackwell, 1992, p. 61.

${ }^{13}$ Rowe, op cit. pp. 15-16.

${ }^{14}$ Ibid., p. 16.

${ }^{15}$ R.Boycott, 'The price of beauty,' Spare Rib 16, 1973, pp. 33-36.

16 ‘Day nursery revolution,' Spare Rib 17, 1973, pp. 33-36.

${ }^{17}$ D. Riley, Am I That Name? Feminism and the Category of 'Women' in History, Macmillan, 1988, pp. 4-5.

${ }^{18}$ See for example C. Morell, 'With a little help from ourselves,' Spare Rib 15, 1973 and A. Carter, 'Interception,' Spare Rib 20, 1974, p. 10. 
${ }^{19}$ A. Raeburn. 'Sex,' Spare Rib 13, 1973, p. 16.

${ }^{20} \mathrm{~J}$, Winship, Inside Women's Magazines, Pandora, 1987, p. 137.

${ }^{21}$ See 'Sex page,' Spare Rib 13-18.

22 'The first cow on Chiswick High Road,' Spare Rib 1, 1972; A. Phillips,

'Battered Women,' Spare Rib 17, 1973, p. 32 and 'Rape,' Spare Rib 20, 1974, pp. 30-33.

23 'Rape,' Spare Rib 20, 1974.

${ }^{24}$ Lewis, op cit., p. 62.

${ }^{25}$ Greer, 1970, p. 15.

${ }^{26}$ A. Raeburn, Spare Rib 17, 1973, p. 11.

27 'Sex,' Spare Rib 17, 1973, p. 11.

28 'Sex,' Spare Rib 21, 1974, p. 7.

29 'How the real half dress,' Spare Rib 1, 1972, pp. 20-21, and J. Reuter, 'Face value,' Spare Rib 1, 1972, p. 16.

${ }^{30}$ A. Coote, 'Put a her in your Hertz,' Spare Rib 8, 1973, pp. 18-19.

${ }^{31}$ Winship, op cit., p. 137.

32 Spare Rib 20, p. 16.

${ }^{33}$ Co-operative Wholesale Society, Annual, 1886, p. 115, quoted in S. Yeo (ed.), New Views of Co-operation, Routledge, 1988, p. 7.

${ }^{34}$ A. Paczuska in Wandor, op cit., p. 156, and Wandor, 'Introduction,' ibid., p. 1 .

${ }^{35}$ C. Steedman, Landscape for a Good Woman, Virago, 1986, p. 24. 
${ }^{36}$ Rowbotham, op cit., p. 244.

${ }^{37}$ Greer, op cit., p. 45.

${ }^{38}$ K, Durbin, 'A weight off my head,' Spare Rib 18, 1973, p. 16.

${ }^{39}$ Reuters, Spare Rib 1, 1972.

${ }^{40}$ L. Gambles, ‘40 Carats,' Spare Rib 21, 1974, p. 43.

${ }^{41}$ See Winship, op cit., p. 34, for a discussion of this.

${ }^{42}$ Ibid., p. 133.

\section{Bibliography}

Spare Rib issues 1-21, June 1972 to March 1974

Ballaster, R. (1991) Women's Worlds: Ideology, Femininity and the Women's Magazine Macmillan

Braithwaite, B. (1995) Women's Magazines: The First 300 Years Peter Owen

Caine, B. (1997) English Feminism 1780-1980 OUP

Carter, A. (1988) The Politics of Women's Rights Longman

Coote, A. \& Campbell, B. (1987) Sweet Freedom Blackwell

Greer, G. (1970) The Female Eunuch MacGibbon

Heron. L (ed.) (1985) Truth, Dare or Promise: Girls Growing Up in the Fifties Virago

Jeffreys, S. (1990) Anticlimax: A Feminist Perspective on the Sexual Revolution Women's Press

Lewis. J. (1992) Women in Britain Since 1945 Blackwell 
Millen, K. (1971) Sexual Politics Hart-Davis

Oakley, A. (1974) Housewife Allen Lane

Oakley, A. (1984) Taking it Like a Woman Cape

Rowbotham, S. (1972) Women, Resistance and Revolution Allen Lane

Rowbotham, S. (1973) Hidden from History Pluto Press

Rowbotham, S. (1973) Woman's Consciousness, Man's World Penguin

Rowe, M. (ed.) (1982) Spare Rib Reader Penguin

Wandor, M. (ed.) (1972) The Body Politic Stage One

Wandor, M. (1990) Once a Feminist Virago

Winship, J. (1987) Inside Women's Magazines Pandora 